\title{
Citrus viroid V: Occurrence, Host Range, Diagnosis, and Identification of New Variants
}

\author{
P. Serra, M. Eiras, S. M. Bani-Hashemian, N. Murcia, \\ E. W. Kitajima, J. A. Daròs, R. Flores, and N. Duran-Vila
}

First author: Centro de Protección Vegetal y Biotecnología, Instituto Valenciano de Investigaciones Agrarias, Apartado Oficial, 46113Moncada, Valencia, Spain; second author: Instituto de Biología Molecular y Celular de Plantas (CSIC-Universidad Politécnica de Valencia), Avenida de los Naranjos s/n, 46022 Valencia, Spain; third and fourth authors: Centro de Protección Vegetal y Biotecnología, Instituto Valenciano de Investigaciones Agrarias, Apartado Oficial, 46113-Moncada, Valencia, Spain; fifth author: Núcleo de Microscopia Eletrônica, Escola Superior de Agricultura Luiz de Queiroz, USP, Piracicaba, Brazil; sixth and seventh authors: Instituto de Biología Molecular y Celular de Plantas (CSIC-Universidad Politécnica de Valencia), Avenida de los Naranjos s/n, 46022 Valencia, Spain; and eighth author: Centro de Protección Vegetal y Biotecnología, Instituto Valenciano de Investigaciones Agrarias, Apartado Oficial, 46113Moncada, Valencia, Spain.

Current address of second author: Laboratório de Fitovirologia e Fisiopatologia, Centro de Pesquisa e Desenvolvimento de Sanidade Vegetal, Instituto Biológico, São Paulo, SP, Brazil.

Accepted for publication 30 July 2008.

\begin{abstract}
Serra, P., Eiras, M., Bani-Hashemian, S. M., Murcia, N., Kitajima, E. W., Daròs, J. A., Flores, R., and Duran-Vila, N. 2008. Citrus viroid V: Occurrence, host range, diagnosis, and identification of new variants. Phytopathology 98:1199-1204.

The recently described Citrus viroid V (CVd-V) has been proposed as a new species of the genus Apscaviroid within the family Pospiviroidae. Analysis of 64 samples from different citrus-growing areas has shown that $\mathrm{CVd}-\mathrm{V}$ is present in the United States, Spain, Nepal, and the Sultanate of Oman. CVd-V found in six sweet orange sources from the Sultanate of Oman was identical to the reference CVd-V variant, whereas

$\left(\mathrm{CVd}-\mathrm{V}^{\mathrm{ST}}\right)$, and $94.9 \%\left(\mathrm{CVd}-\mathrm{V}^{\mathrm{NE}}\right)$ were identified in sources from California, Spain, and Nepal, respectively. These results suggest that this viroid has not emerged recently and that it is relatively widespread. Transmission assays to sweet orange, mandarin, and mandarin hybrids, clementine, satsuma, lemon, sour orange, Tahiti lime, Palestine sweet lime, calamondin, bergamot, and kumquat have shown that all these citrus species and citrus relatives are hosts for CVd-V. Several indexing approaches, including slot blot, northern blot hybridization, and reverse transcription-polymerase chain reaction, have been evaluated for detecting CVd-V, either using Etrog citron as an amplification host or directly from commercial species and cultivars.
\end{abstract} three new variants with sequence identities of $98.6 \%\left(\mathrm{CVd}-\mathrm{V}^{\mathrm{CA}}\right), 97.3 \%$
Viroids are nonencapsidated, small, circular, single-stranded RNAs that replicate autonomously when inoculated in their host plants. Citrus spp. are natural hosts of several viroid species of the genera Pospiviroid (Citrus exocortis viroid, CEVd), Hostuviroid (Hop stunt viroid, HSVd), Cocadviroid (Citrus viroid IV, CVd-IV, recently renamed Citrus bark cracking viroid, CBCVd), and Apscaviroid (Citrus bent leaf viroid, CBLVd, and Citrus viroid III, CVd-III, recently renamed Citrus dwarfing viroid, CDVd) (5). In addition, two other citrus viroids (Citrus viroid original source, CVd-OS, and Citrus viroid V, CVd-V) have been proposed as tentative species of the genus Apscaviroid $(7,20)$.

CVd-V has a GC-rich genome of 293 to 294 nucleotides (nts) and its predicted secondary structure of minimum free energy is a rodlike conformation with $68.7 \%$ paired nucleotides. Biological characterization on the indicator Etrog citron (Citrus medica L.) showed that $\mathrm{CVd}-\mathrm{V}$ induces mild but typical symptoms, and that in coinfections it interacts synergistically with either CBLVd or CDVd producing enhanced leaf symptoms and very pronounced dwarfing (20).

Most citrus viroids (CEVd, HSVd, CBLVd, CDVd, and CBCVd) are widespread, usually occurring as complex mixtures coinfecting the same plant. CVd-OS has only been reported in Japan (7).

Corresponding author: N. Duran-Vila; E-mail address: nduran @ivia.es

doi:10.1094/PHYTO-98-11-1199

(C) 2008 The American Phytopathological Society
$\mathrm{CVd}-\mathrm{V}$ was initially identified after transmission to Atalantia citroides, a viroid host that appeared to be immune to CEVd, CBLVd, CDVd, HSVd, and CBCVd but allowed replication of $\mathrm{CVd}-\mathrm{V}$ (2). Even though its origin is uncertain, $\mathrm{CVd}-\mathrm{V}$ was probably present, but overlooked, in the inoculum source containing HSVd and CDVd, two viroids with similar electrophoretic mobility as $\mathrm{CVd}-\mathrm{V}$ in sequential polyacrylamide gel electrophoresis (sPAGE) $(2,4)$. The recent identification of a new variant of $\mathrm{CVd}-\mathrm{V}$ in a tangelo Orlando grown in Spain (21) suggests that this viroid may be more widespread than initially anticipated.

The information available indicates that all citrus species and most species of citrus-related genera sustain replication of citrus viroids that reach variable titers (1). Even though citrus viroids elicit diseases in sensitive hosts such as exocortis and cachexia (17-19) or affect tree size and crop (23), most susceptible species act as symptomless carriers in which viroids may be overlooked unless they are subjected to indexing tests.

The present work reports (i) the characterization of new variants of $\mathrm{CVd}-\mathrm{V}$ in sources from California and Nepal, (ii) the identification of additional sources of $\mathrm{CVd}-\mathrm{V}$, (iii) the identification of additional hosts of $\mathrm{CVd}-\mathrm{V}$, and (iv) the screening of currently available viroid detection tools for $\mathrm{CVd}-\mathrm{V}$ indexing.

\section{MATERIALS AND METHODS}

Viroid sources. Unless otherwise stated, viroid sources were graft-inoculated on the sensitive selection 861-S1 of Etrog citron 
grafted on rough lemon ( $C$. jambhiri Lush.) rootstock and maintained at 28 to $32^{\circ} \mathrm{C}$ for at least 6 months before nucleic acid extraction. One of the viroid sources, provided by J. S. Semancik (Department of Plant Pathology, University of California, Riverside), was recovered from Etrog citron after a series of transmission assays. Additional sources were collected in different citrusgrowing countries: Spain (18 samples), Brazil (15 samples), Italy (4 samples), Colombia (16 samples), Turkey (3 samples), Sultanate of Oman (6 samples), and Nepal (1 sample). These samples included a range of commercial species: sweet orange $(C$. sinensis (L.) Osb.), mandarin (C. reticulata Blanco), tangor (C. reticulata $\times C$. sinensis $)$, tangelo $(C$. paradisi $\times C$. tangerina $)$, lemon $(C$. limon (L.) Burn.f.), Tahiti lime (C. latifolia Tan.), Mexican lime (C. aurantifolia (Christm.) Swing.), and citron.

Nucleic acid extraction. Tissue samples ( $5 \mathrm{~g}$ of young leaves and/or stem bark) were homogenized in a mixture of phenol and extraction buffer $(0.4 \mathrm{M}$ Tris-HCl, $\mathrm{pH} 8.9 ; 1 \%$ [wt/vol] sodium dodecyl sulfate [SDS]; $5 \mathrm{mM}$ EDTA, $\mathrm{pH} 7.0$; and 4\% [vol/vol] 2-mercaptoethanol). Total nucleic acids were partitioned in $2 \mathrm{M}$ $\mathrm{LiCl}$ and the soluble fraction was concentrated by ethanol precipitation and resuspended in $300 \mu \mathrm{l}$ of TKM buffer $(10 \mathrm{mM}$ Tris$\mathrm{HCl}, \mathrm{pH} 7.4 ; 10 \mathrm{mM} \mathrm{KCl}$; and $0.1 \mathrm{mM} \mathrm{MgCl}$ ) (17).

PAGE. Aliquots $(20 \mu \mathrm{l})$ of the nucleic acid preparations (equivalent to $333 \mathrm{mg}$ of fresh weight tissue) were fractionated by nondenaturing PAGE in a 5\% gel that was stained with ethidium bromide (8). For sPAGE, the segment of this gel delimited by CEVd and 7S RNA was cut and applied onto a second denaturing gel containing $8 \mathrm{M}$ urea $(13,16)$, which following electrophoresis was stained with silver (6).

Northern blot, slot blot, and imprint hybridization. For northern blot hybridization, the RNAs separated by PAGE or sPAGE were electroblotted (400 $\mathrm{mA}$ for $2 \mathrm{~h}$ ) to positively charged nylon membranes (Roche Applied Science) using TBE buffer ( $90 \mathrm{mM}$ Tris, $90 \mathrm{mM}$ boric acid, and $2 \mathrm{mM}$ EDTA). For slot blot hybridization, samples $(10 \mu \mathrm{l})$ were pretreated in $6 \times \mathrm{SSC}$ ( $1 \times \mathrm{SSC}$ is $0.15 \mathrm{M} \mathrm{NaCl}$ plus $0.015 \mathrm{M}$ sodium citrate) containing $8 \%$ formaldehyde for $15 \mathrm{~min}$ at $60^{\circ} \mathrm{C}$ and blotted onto the membrane. For imprint hybridization, freshly-cut stem sections were firmly pressed onto the membrane (14). In all instances, RNAs were immobilized by UV cross-linking and hybridized with ${ }^{32} \mathrm{P}$ RNA or digoxigenin (DIG)-labeled DNA probes.

Viroid-specific riboprobes were synthesized by hydrolysis of a purified viroid RNA preparation followed by 5 '-end labeling with polynucleotide kinase and $\left[\gamma-{ }^{32} \mathrm{P}\right] \mathrm{ATP}$ essentially as described earlier (10) with minor modifications (20). DIG-labeled DNA probes were PCR-synthesized as described by Palacio et al. (11) using a plasmid containing the full-length $\mathrm{CVd}-\mathrm{V}$ sequence and a pair of specific primers.

Prehybridization (at 50 or $60^{\circ} \mathrm{C}$ for 2 to $4 \mathrm{~h}$ ) and hybridization (at 50 or $60^{\circ} \mathrm{C}$ overnight) were performed in $6 \times$ SSPE $(1 \times$ SSPE is $0.18 \mathrm{M} \mathrm{NaCl}, 10 \mathrm{mM} \mathrm{NaPO}_{4}$, and $1 \mathrm{mM}$ EDTA [pH 7.4]) containing $50 \%$ formamide as described by Sambrook et al. (15). After hybridization the membranes were washed twice in $2 \times \mathrm{SSC}$, $0.1 \% \mathrm{SDS}$ at room temperature for $15 \mathrm{~min}$, once in $0.1 \times \mathrm{SSC}$, $0.1 \% \mathrm{SDS}$ at $60^{\circ} \mathrm{C}$ for $60 \mathrm{~min}$, and revealed by autoradiography (radiolabeled probes) or with an anti-DIG alkaline phosphatase conjugate and the chemiluminiscence substrate CSPD (Roche Applied Science) (DIG-labeled probes).

Viroid characterization. Aliquots of nucleic acid preparations from viroid-infected citrons were examined by sPAGE, and the viroid circular forms were eluted overnight from the ethidium bromide stained gel with TEP buffer $(0.1 \mathrm{M}$ Tris-HCl, $\mathrm{pH} 9.0$, containing $0.1 \mathrm{M}$ 2-mercaptoethanol, $10 \mathrm{mM}$ EDTA, and 1\% SDS) in the presence of phenol/chloroform. The RNAs were recovered by ethanol precipitation and resuspended in water. Viroid cDNA clones were obtained by an approach that uses minimal amounts of template and does not require prior knowledge of its sequence $(9,20)$. The PCR-amplified products were ligated into vector $\mathrm{pTZ57R/T}$ (Fermentas) with protruding 3 '-terminal Ts and, following transformation of Escherichia coli DH5 $\alpha$ cells, the plasmid inserts resulting from digestion with $B a m \mathrm{HI}$ and $\mathrm{XbaI}$ were separated by nondenaturing PAGE in 5\% gels, blotted, and hybridized with a 5 '-end labeled viroid-specific probe to identify those containing viroid-cDNAs.

Sequencing and sequence analysis. Reverse transcriptionpolymerase chain reaction (RT-PCR) amplicons or cloned viroidcDNAs were sequenced with an ABI PRISM DNA sequencer 377 (Perkin Elmer). Multiple alignments were performed using the program Clustal W (22). Secondary structure analyses were obtained with the MFOLD program (circular version) from the GCG package (25) and the RNAviz program (3).

Host range and detection studies. A selection of 18 genotypes of different citrus species and cultivars were graft-propagated on rough lemon and graft-inoculated with a $\mathrm{CVd}-\mathrm{V}$ isolate. The selected genotypes were 'Sanguinelli', 'Salustiana', and 'Ricart navelina' sweet oranges, 'Oroval' and 'Hernandina' clementines (C. clementina Hort. ex Tan.), 'Fino' and 'Verna' lemons, 'Sevillano' and 'Cajel' sour oranges (C. aurantium L.), 'Clausellina' satsuma (C. unshiu (Mak.) Marc.), Temple mandarin (C. temple Hort. ex Tan.), Tahiti lime, Palestine sweet lime $(C$. limettioides Tan), calamondin (C. madurensis Lour), 'Calabria' bergamot $(C$. bergamia Risso and Pot.), 'Orlando' tangelo ( $C$. paradisi $\times C$. tangerina), 'Nova' mandarin $(C$. clementina $\times[C$. paradisi $\times C$. tangerina $])$, 'Page' mandarin $((C$. paradisi $\times C$. tangerina $) \times C$. clementina), and 'Nagami' kumquat (Fortunella margarita (Lour.) Swing.).

\section{RESULTS}

Characterization of a viroid-like RNA identified in California as a new variant of CVd-V. The results of a series of transmission assays conducted in California revealed the presence of a viroid-like RNA that was transmissible to Etrog citron but not to tomato (Solanum lycopersicum L.), eggplant (Solanum melongena $\mathrm{L}$.), and datura (Datura stramonium L.). As a preliminary attempt to characterize this viroid-like RNA, a nucleic acid preparation from infected Etrog citron was examined by northern blot hybridization with some DIG-labeled viroid-specific probes. A hybridization signal was obtained with the Apple scar skin viroid (ASSVd) probe but not with the CEVd, HSVd, or CBCVd probes (J. S. Semancik, personal communication). To clone and sequence this viroid-like RNA, nucleic acid preparations were fractionated by sPAGE and the gel-eluted circular forms were used as template for cDNA synthesis using an RT-PCR approach that does not require prior sequence knowledge (9). The cDNAs obtained were mostly in the range of 150 to $300 \mathrm{bp}$ (Fig. 1A, lane 3 ), and some were derived from the viroid-like RNA, as confirmed by Southern blot hybridization with a probe obtained by partial hydrolysis of the viroid-like RNA and 5'-end radiolabeling of the resulting fragments (20) (Fig. 1B, lane 3). The PCRamplified products were cloned into a plasmid vector, and the inserts were analyzed by PAGE after proper restriction (Fig. 1C). Four plasmids containing the largest cDNA inserts of the viroidlike RNA, confirmed by hybridization with the specific probe (Fig. 1D, arrows), were selected for sequencing. The consensus sequence of $88 \mathrm{nts}$ contained a segment of $16 \mathrm{nts}$ identical to the upper central conserved region (CCR) strand of members of the genus Apscaviroid. This consensus sequence differed only in two substitutions $(65 \mathrm{U} \rightarrow \mathrm{A}$ and $69 \mathrm{G} \rightarrow \mathrm{A})$ from the segment of $\mathrm{CVd}-\mathrm{V}$ delimited by positions 39 to 116 (shaded in Fig. 2, CVd-V $\mathrm{V}^{\mathrm{CA}}$ ).

Northern blot hybridization with a full-length $\mathrm{CVd}$-V-specific probe corroborated the sequence similarity of $\mathrm{CVd}-\mathrm{V}$ with the viroid-like RNA, but neither with CDVd nor with HSVd included as controls (Fig. 3A and B). To obtain the complete sequence of the viroid-like RNA the 88-nt consensus sequence was used to design two adjacent primers of opposite polarity (5'-GACGA- 
AGGCCGGTGAGCAGTAAGCC-3') and (5'-GACGACGACAGGTGAGTACTTTC-3') corresponding to $\mathrm{CVd}-\mathrm{V}$ positions 90 to 114 and 69 to 89 , respectively. The cDNA product obtained by RT-PCR amplification of the purified circular forms of the viroidlike RNA exhibited in nondenaturing PAGE the mobility expected for the CVd-V cDNA (data not shown). This cDNA was cloned in a plasmid vector and sequencing of four independent inserts demonstrated that the viroid-like RNA was indeed a 294-nt sequence variant of $\mathrm{CVd}-\mathrm{V}\left(\mathrm{CVd}-\mathrm{V}^{\mathrm{CA}}\right)$. Two of the inserts had identical sequence, which in addition to the substitutions reported above $(65 \mathrm{U} \rightarrow \mathrm{A}, 69 \mathrm{G} \rightarrow \mathrm{A})$ presented two additional transitions $(224 \mathrm{C} \rightarrow \mathrm{U}, 225 \mathrm{C} \rightarrow \mathrm{U})$ in the lower strand of the rodlike secondary structure predicted for $\mathrm{CVd}-\mathrm{V}$ (Fig. 2); their overall sequence identity with the reference variant of $\mathrm{CVd}-\mathrm{V}$ was $98.6 \%$.
The two other inserts differed in two changes each showing that $\mathrm{CVd}-\mathrm{V}^{\mathrm{CA}}$, like $\mathrm{CVd}-\mathrm{V}$, contains a population of sequence variants.

Identification of additional sources and variants of $\mathrm{CVd}-\mathrm{V}$. Nucleic acid extracts from Etrog citrons graft-inoculated with 62 field isolates collected in different citrus-growing countries and from one single sweet orange sample collected in Nepal were examined by northern blot hybridization with a CVd-V-specific DIG-labeled DNA probe. $\mathrm{CVd}-\mathrm{V}$ was identified in one single source of Seminole tangelo (C. paradisi $\times$ C. tangerina) from Spain, in the sweet orange from Nepal, and in six isolates of sweet orange from the Sultanate of Oman.

Identification of $\mathrm{CVd}-\mathrm{V}$ in the Seminole tangelo was accomplished by sPAGE, northern blot hybridization, and RT-PCR as reported by Serra et al. (21). Its complete primary structure was

A

B
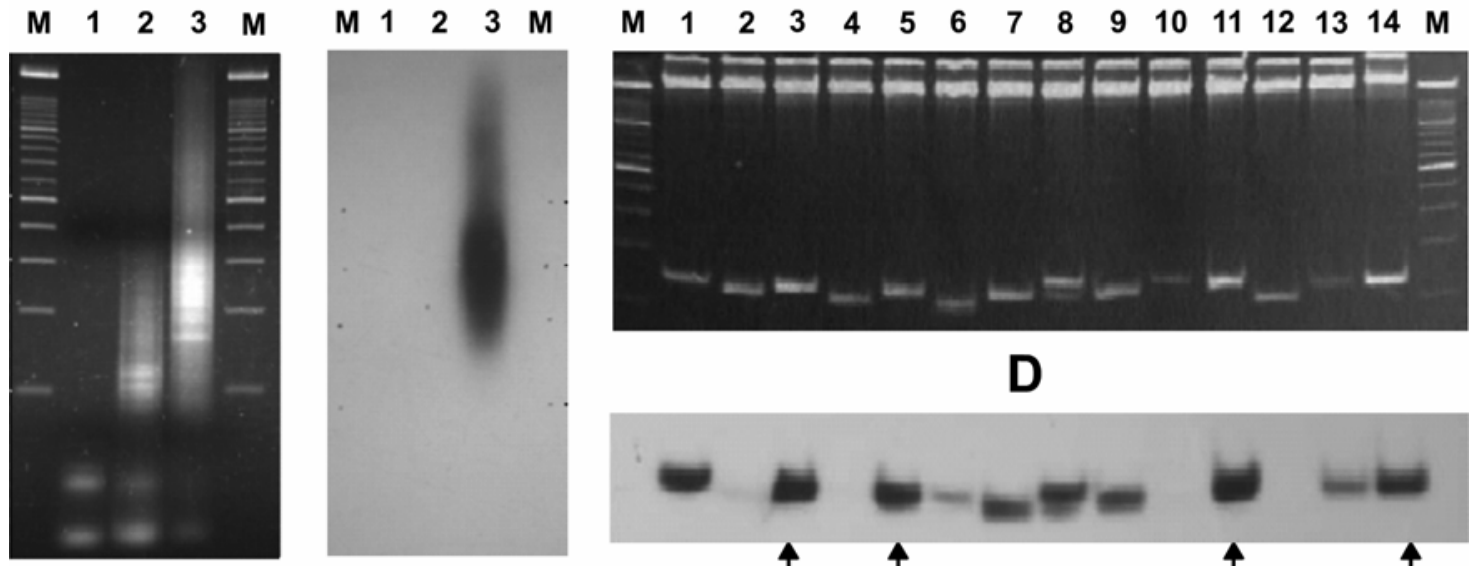

D

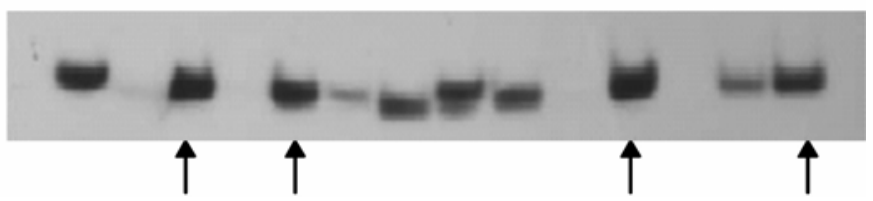

Fig. 1. A, Analysis by nondenaturing polyacrylamide gel electrophoresis and ethidium bromide staining of viroid-like cDNAs obtained by reverse transcriptionpolymerase chain reaction (RT-PCR) with a primer degenerated in its six 3'-terminal positions. Lane 1, PCR control mixture without template; lane 2, RT-PCR control mixture without template; lane 3, complete RT-PCR mixture; and lane M, markers of 100-bp multimers. B, Southern blot analysis of the viroid-like cDNAs with a specific radioactive probe. $\mathbf{C}$, Restriction analysis by nondenaturing polyacrylamide gel electrophoresis and ethidium bromide staining of recombinant plasmids digested with Bam HI and $\mathrm{XbaI}$ (lanes 1 to 14); and lane M, markers of 100-bp multimers. D, Southern blot analysis of the inserts with radioactive probe specific for the viroid-like RNA. Arrows indicate the clones that were sequenced.

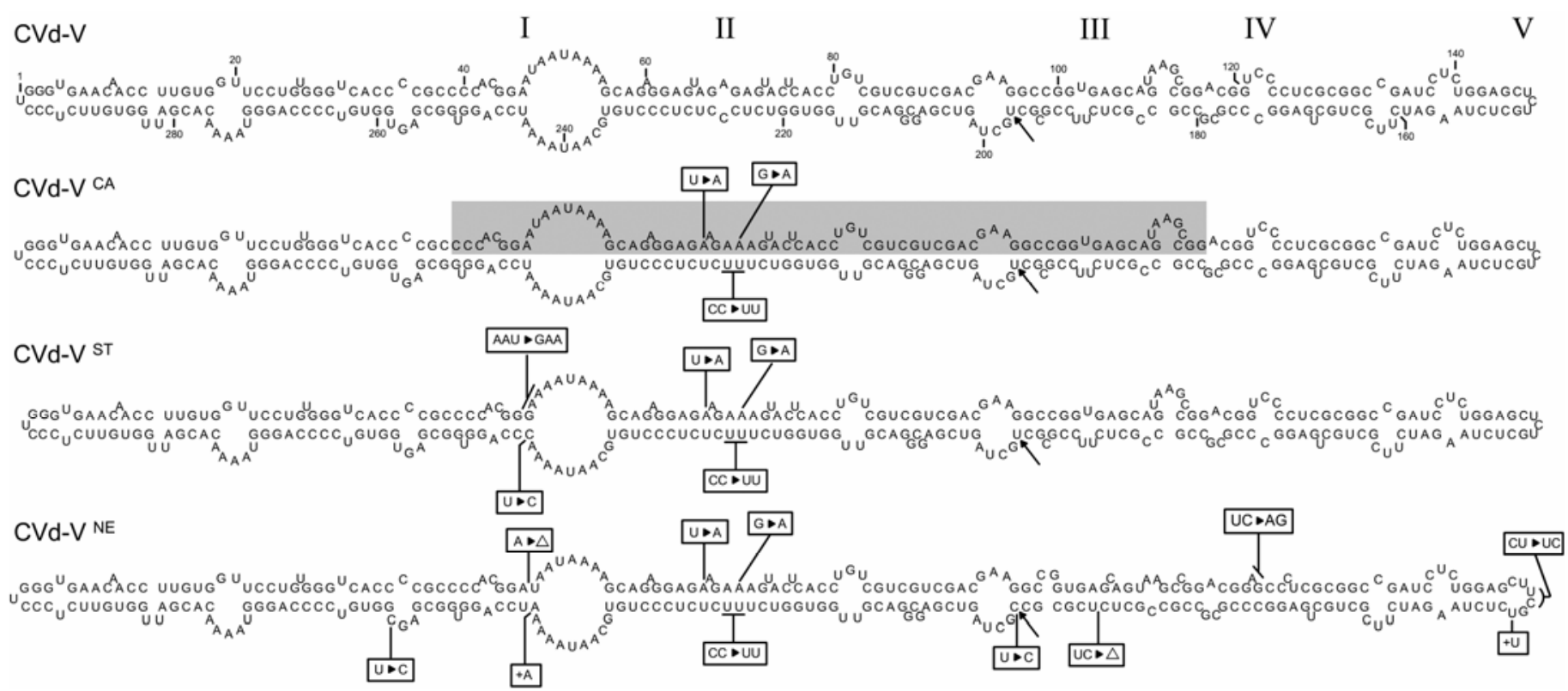

Fig. 2. Primary and predicted secondary structure of minimum free energy of Citrus viroid $V(C V d-V)$ showing the changes identified in the variants obtained from an Etrog citron from California $\left(\mathrm{CVd}-\mathrm{V}^{\mathrm{CA}}\right)$, a Seminole tangelo $\left(\mathrm{CVd}^{\mathrm{ST}}\right)$ from Spain, and a sweet orange from Nepal $\left(\mathrm{CVd}-\mathrm{V}^{\mathrm{NE}}\right)$. The fragment of 88 nucleotides retrieved from the first cloning experiment of $\mathrm{CVd}-\mathrm{V}^{\mathrm{CA}}$ is shaded. Segments I, II, III, IV, and V present deviations of the base pairing between the upper and lower strands as a result of the changes found in $\mathrm{CVd}-\mathrm{V}^{\mathrm{CA}}, \mathrm{CVd}-\mathrm{V}^{\mathrm{S}}$, and $\mathrm{CVd}-\mathrm{V}^{\mathrm{NE}}$. Arrows point at position 197 , which is $\mathrm{U}$ in $\mathrm{CVd}-\mathrm{V}$, $\mathrm{CVd}-\mathrm{V}^{\mathrm{CA}}$, and $\mathrm{CVd}^{\mathrm{ST}}$, instead of $\mathrm{C}$ as in $\mathrm{CVd}-\mathrm{V}^{\mathrm{NE}}$ and in all other members of the genus Apscaviroid. 
determined by sequencing the inserts of three recombinant plasmids containing the amplified cDNAs obtained using two adjacent primers of opposite polarity, with the region covered by the primers being then confirmed by directly sequencing the amplified cDNA obtained with a second set of adjacent primers of opposite polarity (21). This Seminole tangelo variant $\left(\mathrm{CVd}-\mathrm{V}^{\mathrm{ST}}\right)$, with a $98.6 \%$ sequence identity with the reference $\mathrm{CVd}-\mathrm{V}$ variant, presented the same changes identified in $\mathrm{CVd}-\mathrm{V}^{\mathrm{CA}}$ plus two additional changes in the upper and lower strands of the rodlike secondary structure (Fig. 2).

Northern blot hybridizations showed the presence of $\mathrm{CVd}-\mathrm{V}$ in the sweet orange collected in Nepal (Fig. 3C) and six Etrog citrons graft-inoculated with six field isolates of sweet orange ('Baladi', 'Washington Navel', 'Valencia', and 'Succari') collected in two locations (Tanuf and Sohar) in the Sultanate of
Oman (Fig. 3D). These results were confirmed by RT-PCR using two pairs of adjacent primers of opposite polarity, PI and PII, or PIII and PIV (20). The consensus sequences obtained for the amplicons of the six sources from the Sultanate of Oman were identical to the reference $\mathrm{CVd}-\mathrm{V}$ variant. The amplified product obtained from the isolate from Nepal was cloned into the pGEM$\mathrm{T}$ vector (Promega), and sequencing of the inserts of four recombinant plasmids showed that three had identical 293-nt sequences $\left(\mathrm{CVd}-\mathrm{V}^{\mathrm{NE}}\right)$, which differed from that of the reference $\mathrm{CVd}-\mathrm{V}$ variant in 15 positions (Fig. 2), whereas the remaining insert presented an additional $124 \mathrm{C} \rightarrow \mathrm{U}$ substitution.

Molecular characteristics of $\mathbf{C V d}-\mathrm{V}$ variants. The three $\mathrm{CVd}-\mathrm{V}$ variants identified in the present study differed in four $\left(\mathrm{CVd}-\mathrm{V}^{\mathrm{CA}}\right)$, eight $\left(\mathrm{CVd}-\mathrm{V}^{\mathrm{ST}}\right)$, and 15 to 16 changes $\left(\mathrm{CVd}-\mathrm{V}^{\mathrm{NE}}\right)$ from the reference $\mathrm{CVd}-\mathrm{V}$ variant (20). These three variants have
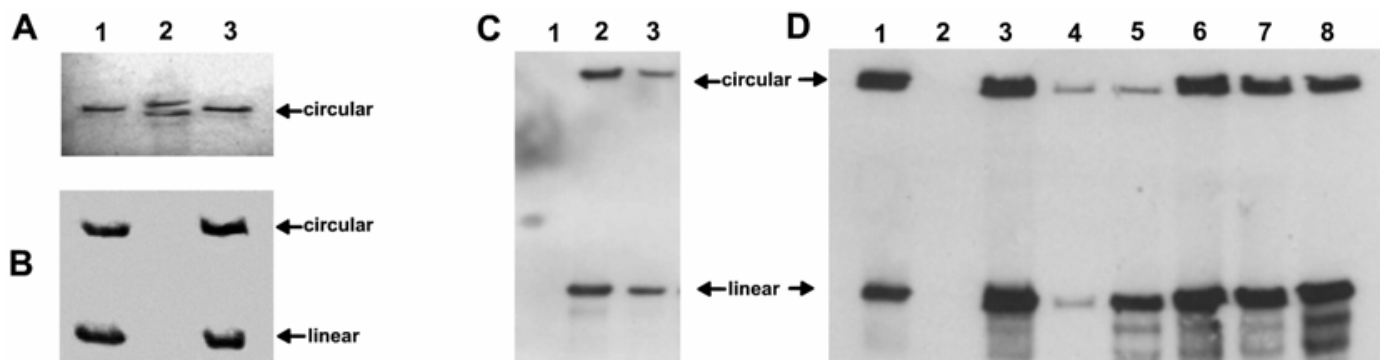

Fig. 3. Detection of Citrus viroid V (CVd-V) in samples from A and B, California, C, Nepal, and $\mathbf{D}$ the Sultanate of Oman. The sample from California was analyzed by $\mathbf{A}$, sequential polyacrylamide gel electrophoresis and silver staining and $\mathbf{B}$, northern blot hybridization with a CVd-V-specific probe: (lane 1) Etrog citron infected with the viroid-like RNA from California; (lane 2) Etrog citron coinfected with Hop stunt viroid and Citrus dwarfing viroid used as a negative control; and (lane 3) Etrog citron infected with CVd-V used as a positive control. C, Samples from Nepal were analyzed by northern blot hybridization with a CVd-V-specific probe: (lane 1) noninoculated Etrog citron used as a negative control; (lane 2) Etrog citron infected with CVd-V used as a positive control; (lane 3) sweet orange collected in Nepal. D, Samples from the Sultanate of Oman were analyzed by northern blot hybridization with a CVd-V-specific probe: (lane 1) Etrog citron infected with CVd-V used as a positive control; (lane 2) noninoculated Etrog citron used as a negative control; (lanes 3 to 8 ) Etrog citrons graftinoculated with 'Baladi' (lanes 3 to 4), Washington navel (lane 5), Succari (lanes 6 to 7), and Valencia (lane 8) sweet orange sources collected in the Sultanate of Oman.

$\begin{array}{llllllll}1 & 2 & 3 & 4 & 5 & 6 & 7\end{array}$

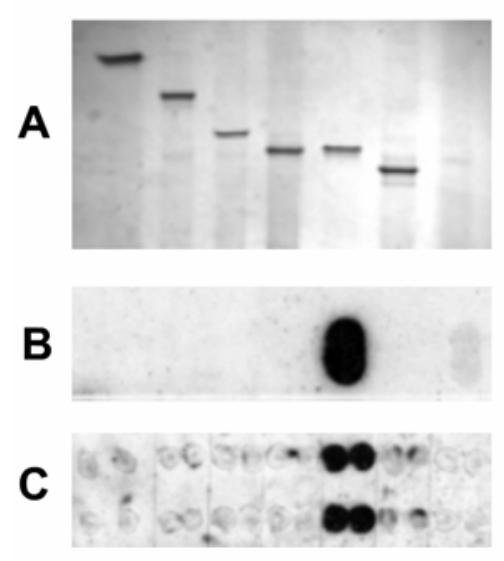

$\begin{array}{llllllllll}1 & 2 & 3 & 4 & 5 & 6 & 7 & 8 & 9 & 10\end{array}$
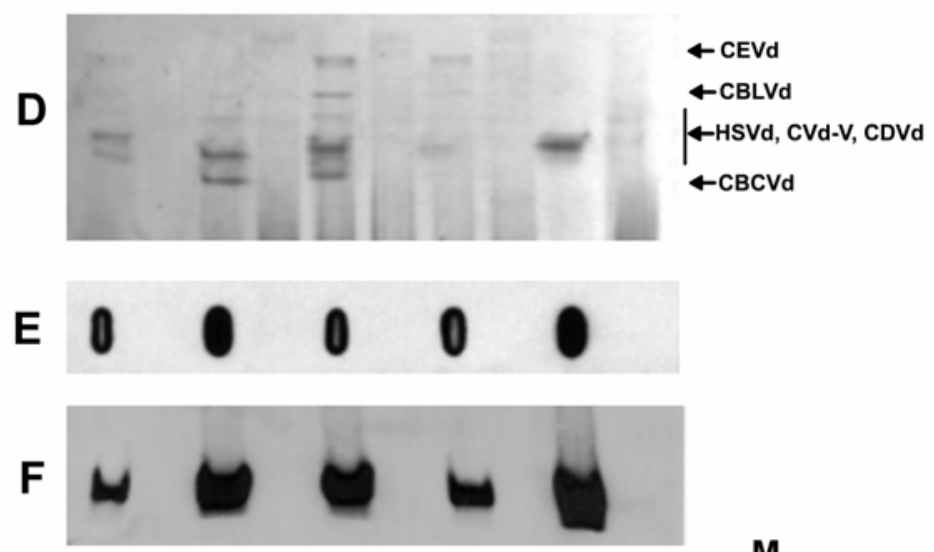

M

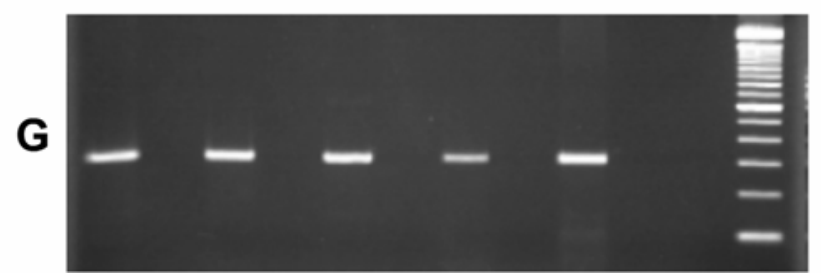

Fig. 4. Detection of Citrus viroid V (CVd-V) in Etrog citron by A, sequential polyacrylamide gel electrophoresis (sPAGE), B, dot blot hybridization, and C, imprint hybridization using a CVd-V-specific probe. Samples were from Etrog citrons infected with (lane 1) Citrus exocortis viroid (CEVd), (lane 2) Citrus bent leaf viroid (CBLVd), (lane 3) Hop stunt viroid (HSVd), (lane 4) Citrus dwarfing viroid (CDVd), (lane 5) CVd-V, (lane 6) Citrus bark cracking viroid (CBCVd), and (lane 7) from a noninfected control. Detection of $\mathrm{CVd}-\mathrm{V}$ in sweet orange, clementine, Tahiti lime, and lemon by D, sPAGE, E, dot, and F, northern blot hybridization with a CVd-V-specific probe, and $\mathbf{G}$, reverse transcription-polymerase chain reaction with $\mathrm{CVd}-\mathrm{V}$-specific primers. Samples were collected from sweet orange, clementine, Tahiti lime and lemon plants coinoculated with CEVd, CBLVd, HSVd, CDVd, CBCVd, and CVd-V (lanes 1, 3, 5, and 7) and from noninoculated controls of the same species (lanes 2, 4, 6, and 8). Samples from Etrog citrons infected with CVd-V (lane 9) and noninoculated (lane 10) were included as controls. Lane M, markers of 100-bp multimers. 
a predicted rodlike secondary structure of minimal free energy with $69.4 \%\left(\mathrm{CVd}-\mathrm{V}^{\mathrm{CA}}\right.$ and $\left.\mathrm{CVd}-\mathrm{V}^{\mathrm{ST}}\right)$ and $71.7 \%\left(\mathrm{CVd}-\mathrm{V}^{\mathrm{NE}}\right)$ paired nucleotides (Fig. 2). Among the changes with respect to the reference $\mathrm{CVd}-\mathrm{V}$ variant there is a cluster of four substitutions in the upper $(65 \mathrm{U} \rightarrow \mathrm{A}$ and $69 \mathrm{G} \rightarrow \mathrm{A})$ and lower $(224 \mathrm{C} \rightarrow \mathrm{U}$, $225 \mathrm{C} \rightarrow \mathrm{U})$ strands of the rodlike secondary structure resulting in an extended base pairing (region II in Fig. 2). The changes of the left side of $\mathrm{CVd}-\mathrm{V}^{\mathrm{ST}}$ are located in a large loop except for two compensatory mutations that switch an A-U pair adjacent to the large loop into a G-C pair in $\mathrm{CVd}-\mathrm{V}^{\mathrm{ST}}$, or into two A-U pairs in $\mathrm{CVd}-\mathrm{V}^{\mathrm{NE}}$ (region I in Fig. 2). No deviations from the predicted secondary structure were found in the right side of $\mathrm{CVd}-\mathrm{V}^{\mathrm{CA}}$ and $\mathrm{CVd}-\mathrm{V}^{\mathrm{ST}}$. However, the changes in the right side of $\mathrm{CVd}-\mathrm{V}^{\mathrm{NE}}$ result in a theoretical reorganization of the rodlike secondary structure with less conspicuous loops (regions III and IV in Fig. 2) and a prominent terminal right loop (region V in Fig. 2).

Unlike the other members of the genus Apscaviroid, variants $\mathrm{CVd}-\mathrm{V}^{\mathrm{CA}}$ and $\mathrm{CVd}-\mathrm{V}^{\mathrm{ST}}$, but not $\mathrm{CVd}-\mathrm{V}^{\mathrm{NE}}$, present in the lower $\mathrm{CCR}$ strand the transition $\mathrm{C} 197 \rightarrow \mathrm{U}$ reported previously in $\mathrm{CVd}$ $\mathrm{V}$ that results in the change of a $\mathrm{C}-\mathrm{G}$ base pair between the upper and lower strands into a wobble G-U base pair (arrows in Fig. 2).

Indexing methods for detection of CVd-V. As shown for other citrus viroids $(4,12)$, bioamplification in Etrog citron followed by sPAGE (Fig. 4A), slot blot (Fig. 4B), or imprint hybridization (Fig. 4C) are suitable methods for detecting CVd-V. Conversely, direct sPAGE of RNAs from sweet orange, clementine, Tahiti lime and lemon trees that had been coinoculated with CEVd, CBLVd, HSVd, CDVd, CBCVd, and CVd-V led to inconclusive results because of the low and variable viroid titers in these species (Fig. 4D). However, CVd-V could be detected in these species by slot blot (Fig. 4E) or northern blot (Fig. 4F) hybridization with a $\mathrm{CVd}-\mathrm{V}$-specific probe. RT-PCR approaches using $\mathrm{CVd}-\mathrm{V}$-specific primers also gave the expected results (Fig. 4G).

Host range of CVd-V. RNA preparations from 20 citrus genotypes that had been graft-inoculated with the original $\mathrm{CVd}-\mathrm{V}$ source (20) were analyzed by northern blot hybridization with a $\mathrm{CVd}-\mathrm{V}$-specific probe. Results confirmed that all were infected (Fig. 5A), whereas no signals were observed in the noninoculated controls (Fig. 5B).

\section{DISCUSSION}

Transmission studies using Atalantia citroides revealed the existence of a new member of the genus Apscaviroid, which induces mild, but characteristic symptoms on Etrog citron and displays synergistic effects when coinoculated with other members of the same genus $(2,20)$. Even though the original source of $\mathrm{CVd}-\mathrm{V}$ is uncertain, it was most likely present, but overlooked, in

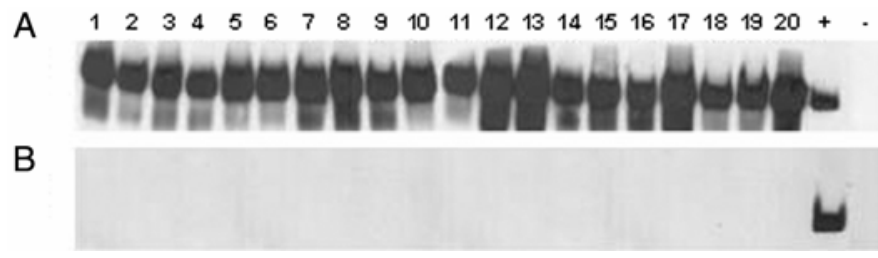

Fig. 5. A, Detection of Citrus viroid V $(\mathrm{CVd}-\mathrm{V})$ by northern blot hybridization with a CVd-V-specific probe in (lane 1) 'Hernandina' clementine, (lane 2) 'Ricart navelina' sweet orange, (lane 3) 'Nagami' kumquat, (lane 4) 'Cajel' sour orange, (lane 5) 'Oroval' clementine, (lane 6) 'Orlando' tangelo, (lane 7) 'Salustiana' sweet orange, (lane 8) 'Clausellina' satsuma, (lane 9) 'Nova' mandarin, (lane 10) 'Page' mandarin, (lane 11) 'Sanguinelli' sweet orange, (lane 12) 'Fino' lemon, (lane 13) Palestine sweet lime, (lane 14) 'Verna' lemon, (lane 15) calamondin, (lane 16) 'Calabria' bergamot, (lane 17) 'Clemenules' clementine, (lane 18) 'Sevillano' sour orange, (lane 19) 'Temple' mandarin, and (20) Tahiti lime. Plants were inoculated with a CVd-V source. B, Absence of $\mathrm{CVd}-\mathrm{V}$ in noninoculated plants of the same species. Etrog citrons infected with $\mathrm{CVd}-\mathrm{V}(+)$ and noninoculated (-) were included as controls. field sources containing HSVd or CDVd, which have electrophoretic mobilities in SPAGE similar to $\mathrm{CVd}-\mathrm{V}$. Detection of $\mathrm{CVd}-\mathrm{V}$ in diverse hosts collected in different citrus-growing areas (Spain, United States, Nepal, and Sultanate of Oman) indicates that even though this viroid does not seem to be as widespread as other citrus viroids, it might have remained unnoticed in indexing programs. The identification of sequence variants that differ from $\mathrm{CVd}-\mathrm{V}$ in four $\left(\mathrm{CVd}-\mathrm{V}^{\mathrm{CA}}\right)$, eight $\left(\mathrm{CVd}-\mathrm{V}^{\mathrm{ST}}\right)$, and 15 to $16(\mathrm{CVd}-$ $\mathrm{V}^{\mathrm{NE}}$ ) changes, four of which $(\mathrm{U} 65 \rightarrow \mathrm{A}, \mathrm{G} 69 \rightarrow \mathrm{A}, \mathrm{C} 224 \rightarrow \mathrm{U}$, and $\mathrm{C} 225 \rightarrow \mathrm{U})$ are present in these three variants, suggests an evolutionary link among them. CVd-V occurrence in different geographic locations is probably the result of exchange of plant material followed by the adaptation of mutants under different environmental conditions.

As reported previously for $\mathrm{CVd}-\mathrm{V}$ (20), the sequence of the upper CCR strand of variants $\mathrm{CVd}-\mathrm{V}^{\mathrm{CA}}, \mathrm{CVd}-\mathrm{V}^{\mathrm{ST}}$, and $\mathrm{CVd}-\mathrm{V}^{\mathrm{NE}}$ is identical to that of the other members of the genus Apscaviroid, while the sequence of the lower CCR strand contains in CVd- $\mathrm{V}^{\mathrm{CA}}$ and $\mathrm{CVd}-\mathrm{V}^{\mathrm{ST}}$ but not in $\mathrm{CVd}-\mathrm{V}^{\mathrm{NE}}$, a $\mathrm{C} 197 \rightarrow \mathrm{U}$ transition that results in the change of a $\mathrm{C}-\mathrm{G}$ base pair between the upper and lower strands into a wobble G-U base pair. Another feature of the new variants identified in the present study is the presence of two sets of changes in the upper and lower strands (U65 $\rightarrow \mathrm{A}$ and $\mathrm{G} 69 \rightarrow \mathrm{A})$ and $(\mathrm{C} 224 \rightarrow \mathrm{U}$ and $\mathrm{C} 225 \rightarrow \mathrm{U})$, which result in a rearrangement of the predicted rodlike secondary structure.

The host range study reported here illustrates that, like other citrus viroids, $\mathrm{CVd}-\mathrm{V}$ can infect all the citrus species and cultivars tested. The phenotypic alterations incited by $\mathrm{CVd}-\mathrm{V}$ infection on commercial species and cultivars are not known, but the synergistic effects described in Etrog citron coinfected with $\mathrm{CVd}-\mathrm{V}$ and CBLVd or CDVd (20) suggest that similar interactions may result in reduced tree size and yield, as reported for clementine trees grafted on trifoliate orange (Poncirus trifoliata L.) coinfected with several viroids (24).

In conclusion, the recently described CVd-V $(20,21)$ is present in a number of citrus-growing areas and at least three new variants have been identified and characterized. Even if the effect of $\mathrm{CVd}-\mathrm{V}$ in commercial rootstock-scion combinations is yet unknown, this viroid must be taken into consideration by agencies involved in phytosanitation, variety improvement, and certification programs.

\section{ACKNOWLEDGMENTS}

This work was supported by grants AGL2005-01469 and BFU200506808/BMC from the Ministerio de Educación y Ciencia of Spain. P. Serra, S. M. Bani-Hashemian and N. Murcia received fellowships from the Consellería de Agricultura-IVIA, Spain, the Iran Citrus Research Institute, and CORPOICA, Colombia, respectively. M. Eiras was the recipient of a predoctoral fellowship from Conselho Nacional de Desenvolvimento Científico e Tecnológico, Brazil. We thank J. S. Semancik, J. A. Szychowski, and G. Vidalakis (University of California, Riverside), E. Sanches Stuchi (Estação Experimental de Citricultura de Bebedouro, SP, Brazil), N. A. Wulff (Fundecitrus, Araraquara, SP, Brazil), J. J. Rivera, and A. E. Diaz (CORPOICA, Colombia), K. Bederski (Topara Nursery, Peru), W. Davino, and M. Davino (Universita degli Studi di Catania, Italy), Y. M. Al-Raeesy (Crop Protection Research Center, Seeb, Oman), H. Dietz (Directorate General of Agriculture and Veterinary Services, Royal Court Affairs, Sohar, Oman), and J. M. Bové (INRA and Université de Bordeaux 2, Villenave d'Ornon cedex, France) for providing some of the samples used in this study, and R. Carbó for technical assistance.

\section{LITERATURE CITED}

1. Barbosa, C., Pina, J. A., Navarro, L., and Duran-Vila, N. 2002. Replication/acccumulation and symptom expression of citrus viroids on some species of citrus and related genera. Pages 264-271 in: Proc. 15th Conf. IOCV. N. Duran-Vila, R. G. Milne, and J. V. da Graça, eds. IOCV, Riverside, CA. 
2. Barbosa, C., Serra, P., Pina, J. A., Navarro, L., Darós, J. A., Flores, R., and Duran-Vila, N. 2005. Identification and preliminary characterization of a viroid-like RNA in Atalantia citroides. Pages 264-271 in: Proc. 16th Conf. IOCV. M. E. Hilf, N. Duran-Vila, and M. A. Rocha-Peña, eds. IOCV, Riverside, CA.

3. De Rijk, P., and De Wachter, R. 1997. RnaViz, a program for the visualization of RNA secondary structure. Nucleic Acids Res. 25:4679-4684.

4. Duran-Vila, N., Pina, J. A., and Navarro, L. 1993. Improved indexing of citrus viroids. Pages 201-211 in: Proc. 12th Conf. IOCV. P. Moreno, J. V. da Graça, and L. W. Timmer, eds. IOCV, Riverside, CA.

5. Flores, R., Hernández, C., Martínez de Alba, A. E., Daròs, J. A., and Di Serio, F. 2005. Viroids and viroid-host interactions. Annu. Rev. Phytopathol. 43:117-139.

6. Igloi, G.L. 1983. Silver stain for the detection of nanogram amounts of tRNA following two-dimensional electrophoresis. Anal. Biochem. 134:184-188

7. Ito, T., Ieki, H., Ozaki, K., and Ito, T. 2001. Characterization of a new citrus viroid species tentatively termed citrus viroid OS. Arch. Virol. 146:975-982.

8. Morris, T. J., and Wright, N. S. 1975. Detection on polyacrilamide gel of a diagnostic nucleic acid from tissue infected with potato spindle tuber viroid. Am. Potato J. 52:57-63.

9. Navarro, B., Darós, J. A., and Flores, R. 1998. A general strategy for cloning viroids and other small circular RNAs that uses minimal amounts of template and does not require prior knowledge of its sequence. J. Virol. Methods 56:59-66.

10. Negruk, V. I., Grill, L. K., and Semancik, J. S. 1980. In vitro ${ }^{32}$ P-labelling of viroid RNA for hybridization studies. J. Virol. Methods 1:229-234.

11. Palacio, A., Foissac, X., and Duran-Vila, N. 2000. Indexing of citrus viroids by imprint hybridisation. Eur. J. Plant Pathol. 105:897-903.

12. Palacio, A., Foissac, X., and Duran-Vila, N. 2000. Indexing of citrus viroids by imprint hybridization: Comparation with other detection methods. Pages 294-301 in: Proc 14th Conf. IOCV. J. V. da Graça, R. F. Lee, and R. K. Yokomi, eds. IOCV, Riverside, CA.

13. Rivera-Bustamante, R. F., Gin, R., and Semancik, J. S. 1986. Enhanced resolution of circular and linear molecular forms of viroid and viroid-like RNA by electrophoresis in a discontinuous-pH system. Anal. Biochem. 156:91-95.

14. Romero-Durbán, J., Cambra, M., and Duran-Vila, N. 1995. A simple imprint-hybridization method for detection of viroids. J. Virol. Methods
$55: 37-47$.

15. Sambrook, J., Fristch, E. F., and Maniatis, T. 1989. Molecular Cloning: A Laboratory Manual. Cold Spring Harbor Laboratory, Cold Spring Harbor, NY.

16. Sänger, H. L., Ramm, K., Domdey, H., Gross, H. J., Henco, K., and Riesner, D. 1979. Conversion of circular viroid molecules to linear strands. FEBS Lett. 99:117-121.

17. Semancik, J. S., Morris, T. J., and Weathers, L. G. 1973. Structure and conformation of low molecular weight pathogenic RNA from exocortis disease. Virology 53:448-456.

18. Semancik, J. S., Roistacher, C. N., Rivera-Bustamante, R., and DuranVila, N. 1988. Citrus cachexia viroid, a new disease of citrus: Relationship to viroids of the exocortis disease complex. J. Gen. Virol. 69:30593068 .

19. Semancik, J. S., and Weathers, L. G. 1972. Exocortis virus: An infectious free-nucleic acid plant virus with unusual properties. Virology 46:456466.

20. Serra, P., Barbosa, C. J., Daròs, J.A., Flores, R., and Duran-Vila, N. 2008. Citrus viroid V: Molecular characterization and synergistic interactions with other members of the genus Apscaviroid. Virology 370:102-112.

21. Serra, P., Pina, J. A., and Duran-Vila, N. Identification and characterization of a variant of Citrus viroid $V(\mathrm{CVd}-\mathrm{V})$ in Seminole tangelo. Proc. 17th Conf. IOCV. IOCV, Riverside, CA (In press.)

22. Thompson, J. D., Higgins, D. G., and Gibson, T. J. 1994. CLUSTAL W. Improving the sensitivity of progressive multiple sequences alignment through sequence weighting, positions-specific gap penalties and weight matrix choice. Nucleic Acids Res. 22:4673-4680.

23. Vernière, C., Perrier, X., Dubois, C., Dubois, A., Botella, L., Chabrier, C., Bové, J. M., and Duran-Vila, N. 2004. Citrus viroids: Symptom expression and effect on vegetative growth and yield of clementine trees grafted on trifoliate orange. Plant Dis. 88:1189-1197.

24. Vernière, C., Perrier, X., Dubois, C., Dubois, A., Botella, L., Chabrier, C., Bové, J. M., and Duran-Vila, N. 2006. Interactions between citrus viroids affect symptom expression and field performance of clementine trees grafted on trifoliate orange. Phytopathology 96:356-368.

25. Zuker, M., Mathews, D. H., and Turner, D. H. 1999. Algorithms and Thermodynamics for RNA Secondary Structure Prediction: A Practical Guide in RNA Biochemistry and Biotechnology. J. Barciszewski and B. F. C. Clark, eds. NATO ASI Series, Kluwer Academic Publishers, Dordrecht, the Netherlands. 